\title{
CHOOSING A TRAVEL AGENCY FRANCHISE BY MEAN OF A GLOBAL COMPOSITE INDICATOR: AN APPLICATION IN SPAIN
}

\author{
Francisco J. Blancas-Peral ${ }^{1}$, Ignacio Contreras ${ }^{2}$, José M. Ramírez-Hurtado ${ }^{3}$ \\ Department of Economics, Quantitative Methods and Economic History, Pablo de Olavide \\ University, Ctra. de Utrera, km. 1, 41013 Seville, Spain \\ E-mail:1fjblaper@upo.es; ${ }^{2}$ iconrub@upo.es; ${ }^{3}$ jmramhur@upo.es (corresponding author)
}

Received 2 February 2012; accepted 25 April 2012

\begin{abstract}
This paper highlights the complexity of the franchise partner selection process from a franchisee's perspective. The purpose of this article is, firstly, to propose the definition of a system of indicators which include all the relevant information which the potential franchisee should take into consideration when choosing a chain secondly, to obtain a global composite indicator for the construction of a ranking of franchisors. In order to illustrate the procedure, a sample of travel agency franchisors in Spain and a suitable database to quantify the indicators are considered. The paper concludes constructing a complete order of the franchisors in the travel agency industry. In addition, the results show the most important characteristics of franchisors that potential franchisees must take into account. The value of the paper is significant as it provides a practical frame - work for potential franchisees in the selection of franchisors.
\end{abstract}

Keywords: indicator, franchisee, choice of franchisor, data envelopment analysis, travel agency, Spain.

Reference to this paper should be made as follows: Blancas-Peral, F. J.; Contreras, I.; Ramírez-Hurtado, J. M. 2014. Choosing a travel agency franchise by mean of a global composite indicator: an application in Spain, Journal of Business Economics and Management 15(1): 153-173.

JEL Classification: C61, M19, L83.

\section{Introduction}

Franchising represents an important contributor towards the economy of many countries, since it plays a vital role in the development and growth of small businesses (Rahatullah, Raeside 2009). Franchising data from various parts of the world confirms that this business system constitutes a significant and increasingly popular aid to economic growth.

Franchising can be viewed as a particular type of partner selection (Altinay 2006; Clarkin, Swavely 2006; Jambulingam, Nevin 1999) or as a type of collaborative business with the existence of a profit-sharing problem. 
Partner selection between the franchisor and the franchisee is critical to the long-term success of a franchise since franchising is a strategic partnership formed by two agents (Xiao et al. 2008), and hence this selection has remained the subject of research by researchers for many recent decades. The literature has primarily taken the viewpoint of franchisors (Clarkin, Swavely 2006; Jambulingam, Nevin 1999; Taylor 2000), but has largely failed to explore the perspective of the potential franchisee (Xiao et al. 2008). From the franchisee's point of view, great attention has been paid to certain areas, such as to the advantages of the franchise over other forms of commerce (Bates 1995; Dant 1995; Kaufmann 1999; Kaufmann, Stanworth 1995; Knight 1986), and the motives which lead the newcomer to go into franchising (Guilloux et al. 2004; Knight 1986; Peterson, Dant 1990; Ramirez-Hurtado, Quattrociocchi 2009; Kaufmann, Stanworth 1985; Williams 1999; Withane 1991). However, recent literature has barely analysed the question as to which franchise the potential franchisee should choose. An analysis of the literature reveals the need for new research into this question, which would seek a definition of those analytical tools adequate to help the franchisee make the most appropriate decision.

When selecting a franchisor, the potential franchisee must make a decision based on a vast amount of heterogeneous information of a multidimensional nature. The existing recommendations, given by franchise associations, consultants and manuals, are based on the selection of only one or a few variables. This could lead to a serious error, where not all the necessary information is simultaneously taken into account.

The object of this work is, first of all, to propose the definition of a system of indicators which includes all the relevant information that the potential franchisee should take into consideration when choosing a chain. Secondly, the work also aims to obtain a comprehensive composite indicator from a series of strategic dimensions in order to make it possible to establish a ranking of franchisors. In order to achieve the aforementioned goals, a multiplicative aggregation procedure based on the principle of loss of information is used, which takes the work of Zhou et al. $(2006,2010)$ as reference. Based on these studies, a composite indicator is constructed with a common weighting system with the lowest possible degree of subjectivity.

Given the heterogeneity of the existing franchising sectors, the focus of this study is on travel agencies which constitute a highly significant sector in franchising. The justification for using this sector is that it is extremely dynamic, and presents one of the most sustained and major expansions over recent years, thanks to the support it receives from professionals and entrepreneurs in the tourist trade (Franquiciashoy 2008). Without doubt, travel agencies represent one of the most significant sectors of the numerous franchising systems worldwide.

This work differs from previous research in two aspects. First, this paper highlights the complexity of the franchise-partner selection process from a franchisee's perspective. Secondly, this paper states a ranking of franchisors by means of the use of a composite indicator. From a practical point of view, this work eases the decision-making process for those entrepreneurs who wish to join a franchise chain. For academics, this work 
contributes towards the meagre literature available on partner selection in franchising from the perspective of the franchisee.

The structure of this work is as follows: in Section 1, the problem of the choice of franchisor from the point of view of the potential franchisee is presented. Section 2 shows certain major issues about strategic dimensions and indicators for the selection of a franchisor. Section 3 explains the methodology proposed for the attainment of the composite indicator. Section 4 summarises the results obtained using Spanish travel agencies and presents the discussion on these results. Finally, the managerial implications, conclusions, drawbacks and future lines of research are presented.

\section{The problem of the choice of franchisor}

In spite of the importance of franchising, the literature on this subject continues to be vague and incomplete (Altinay, Wang 2006). Elango and Fried (1997) review the literature on franchising, and propose ideas on future research. Along these lines, the selection process of a franchisee by the franchisors has been widely studied, although the inverse process remains to be explored. Previous literature has focused on franchisee selection and the importance of recruiting and selecting suitable candidates. However, the issue of choosing a suitable franchisor has been largely neglected (Lim, Frazer 2003). The agency theory has traditionally considered the franchisor as the principal actor and the franchisee as the agent. However, in many cases, the franchisee is the principal actor since this person is the owner of the majority of the shares (Elango, Fried 1997). Despite the recommendations of Elango and Fried, previous research has indicated that certain studies are necessary to bridge this gap by taking a franchisee viewpoint (Altinay 2006).

This paper does not claim to identify the desired qualities of franchisors. This work strives to help the potential franchisees in the selection a particular franchisor from among all the suitable alternatives.

The selection of a particular franchisor should be supported by a wide number of criteria. Franchisees should take into consideration all the advantages and disadvantages, and their individual expectations in order to make the right decision (Ordiñaga 1995).

The literature suggests that franchising is seen as an important source of profit maximization (Vaishnav, Altinay 2009). Financial factors, such as expected returns on investment, value of investment, continued investment, and the risk associated with business, are carefully examined by franchisees prior to making any franchise agreement (Weaven, Frazer 2006).

Moreover, previous research reveals that in partner identification, the pricing factor plays a leading role (Vaishnav, Altinay 2009). Price is associated with the heavy amount of capital investment. Experience also constitutes a major factor in the selection of a franchisor (Al-Khalifa, Peterson 1999). Prospective franchisees seek franchisors who exhibit a high level of experience.

The evaluation of these and other criteria presents an indicator of the scope for franchisees to work effectively and to build a successful partnership (Vaishnav, Altinay 2009). 
One of the main data sources considered by potential franchisees is provided by business directories, which are published by consultants and associations. In these reports, most of the relevant criteria referred to above can be found.

These directories summarise the main data on franchisors who operate within the country, and include contact data, and strategic variables. For a potential franchisee, the selection process can be a hard task since the interpretation of the figures can vary from one chain to another. In Spain alone, there exist more than 1,000 franchises, all with different requirements about entry fee, royalties and/or contract length. Therefore, a potential franchisee has to consider a huge volume of information, which transforms the selection process into a daunting task.

A highly useful tool that helps the potential franchisees in the selection process is the construction of rankings. However, most of the rankings published by specialized consultants or associations only take into consideration one particular variable, thereby giving only a partial solution to a complex problem. These values enable the potential investors to make comparisons, but only in terms of one measure. A correct comparison should include all the relevant information about all the franchisors simultaneously. A further aspect which must be considered is that most of the published rankings have yet to be studied and analysed in a systematic way.

In short, this work strives to help franchisees in the selection of a chain, by means of providing a ranking of franchisors which features their most significant characteristics.

\section{Strategic dimensions and indicators for the selection of a franchisor}

The directories on franchising publish a set of strategic variables of each franchisor. This information can easily be consulted by potential franchisees or by interested investors. In order to select the most adequate franchisor, the future franchisee must consider a multitude of key factors so that a comparative analysis can be made of the various chains operating in the desired sector. Therefore, the only way of performing a rigorous selection is to gather as much information as possible, in order to be able to analyse the highest number of relevant aspects.

In this work, a system of indicators is defined that provides information relative to those key factors which determine the strategy of each brand operating in the sector under study and which, therefore, cannot be modified in the short term. The analysis of these strategic indicators makes it possible to evaluate the competitive position of each brand within the sector in relation to its competitors, so that franchisees may identify those brands which best match their own interests.

In order to define the proposed system of indicators, previous studies relating to the identification of strategic groups within the franchise system have been taken as reference (Carney, Gedajlovic 1991; Castrogiovanni et al. 1995; López, Ventura 2002; Rondán et al. 2007). In this context, the strategic group is understood to be the set of companies within a sector which follow the same or similar strategy based on the analysis of a series of strategic dimensions (Porter 1979). The strategic dimension is 
considered to be composed of those aspects linked to company strategy which provide it with a competitive advantage in respect to its competitors in the sector. The conclusion drawn from the analysis of these studies is that the proposed system for the selection of the most adequate franchisor is comprised of the indicators stated in Table 1, which are shown grouped together into seven basic strategic dimensions.

Each of these strategic dimensions may have a positive or negative influence on the potential franchisee's assessment of which franchisor should be selected. In this work, in addition to the common dimensions of size, dispersion, growth, joining fee, and length of contract, yet another strategic dimension, that of result indicators, is also taken into consideration, since the most effective companies are those whose business strategies lead to better results (Pereira et al. 2009; Rondán et al. 2010).

In general, a high number of branches throughout the country under consideration, together with a large number of outlets of the chain worldwide, have a positive influence on the potential franchisee due to the obvious extent of experience accumulated by the franchisor. The experience accumulated in a certain period of time depends on the size of the franchisor (Castrogiovanni et al. 1993). Franchisors with many franchisee units gain a lot of experience since they must deal simultaneously with several markets, whereas franchisors with only a few franchisee units only gain experience in a minimum number of markets. As franchisors gain experience, they are better trained to identify qualified franchisees. In fact, many franchisors, when selecting franchisees, change the characteristics required of potential franchisees thanks to the experience they have gained over time (Forward, Fulop 1993). These indicators therefore have a positive influence on the potential franchisee, although there may sometimes be a franchise chain with fewer outlets which satisfies franchisees more in terms of other factors, such as level of profitability, and relationship with the franchisor, when compared with a franchise with a greater number of branches.

Furthermore, the indicators related to growth have a positive influence on the potential franchisee since this also implies greater experience on the part of the franchisor. According to Forward and Fulop (1993), experience accumulated by each franchisor should have a good effect, not only in obtaining a better selection of franchisees, but also in many other aspects, which include: improvement of the training process to be carried out with franchisees; a more effective contract on payment; and location of the stores in strategic geographic zones. Peterson and Dant (1990) indicate that the longer franchisees have become part of the chain positively influences the whole system.

With regards to the entry fee, this may or may not cover the training of staff, and the decoration of the business premises. Moreover, royalty payments sometimes include promotion expenditures, while in other cases the franchisee has to make extra payments. Nevertheless, as a general rule, the indicators related to the cost of adhesion have a negative influence on the franchisee preferences.

Along these lines, indicators related to the length of time that the franchise is in existence has a positive influence on the potential franchisee. The accumulated experience not only depends on the size of franchisor, but is also related to the age of the company. 
F. J. Blancas-Peral et al. Choosing a travel agency franchise by mean of a global composite...

Table 1. Strategic dimensions and indicators

\begin{tabular}{|c|c|c|}
\hline $\begin{array}{c}\text { Strategic } \\
\text { Dimensions }\end{array}$ & Indicators (Operative Variables) & Indicator \\
\hline \multirow{2}{*}{ A. Size } & A1. Total shops throughout the considered country & $\mathrm{I}_{1}$ \\
\hline & A2. Number of outlets of the chain in the world & $\mathrm{I}_{2}$ \\
\hline \multirow{2}{*}{ B. Dispersion } & B1. Internationalization & $\mathrm{I}_{3}$ \\
\hline & B2. Minimum population required & $\mathrm{I}_{4}$ \\
\hline \multirow{3}{*}{ C. Growth } & C1. Outlets opened per year & $\mathrm{I}_{5}$ \\
\hline & C2. Outlets opened per year in the considered country & $\mathrm{I}_{6}$ \\
\hline & $\begin{array}{l}\text { C3. Outlets opened per year from the beginning of the } \\
\text { franchising system }\end{array}$ & $\mathrm{I}_{7}$ \\
\hline \multirow{7}{*}{$\begin{array}{l}D . \text { Cost of } \\
\text { adhesion (price of } \\
\text { franchising) }\end{array}$} & $\begin{array}{l}\text { D1. Average investment that the candidate needs to be a } \\
\text { franchisee }\end{array}$ & $\mathrm{I}_{8}$ \\
\hline & D2. Entry fee ${ }^{1}$ & $\mathrm{I}_{9}$ \\
\hline & D3. Percentage of entry fee over initial investment & $\mathrm{I}_{10}$ \\
\hline & D4. Royalty (percentage of sales) & $\mathrm{I}_{11}$ \\
\hline & D5. Advertising fee (percentage of sales) & $\mathrm{I}_{12}$ \\
\hline & D6. Minimum surface of the place & $\mathrm{I}_{13}$ \\
\hline & D7. Minimum personnel & $\mathrm{I}_{14}$ \\
\hline \multirow{2}{*}{ E. Contract } & E1. Contract length (years) ${ }^{2}$ & $\mathrm{I}_{15}$ \\
\hline & E2. Exclusivity & $\mathrm{I}_{16}$ \\
\hline \multirow{4}{*}{ F. Timing } & $\begin{array}{l}\text { F1. Percentage of franchised units (confidence in } \\
\text { franchising) }\end{array}$ & $\mathrm{I}_{17}$ \\
\hline & F2. Age of the company (years since inception) & $\mathrm{I}_{18}$ \\
\hline & F3. Years franchising & $\mathrm{I}_{19}$ \\
\hline & $\begin{array}{l}\text { F4. Years not franchising (years between inception and } \\
\text { first franchise) }\end{array}$ & $\mathrm{I}_{20}$ \\
\hline \multirow{4}{*}{$\begin{array}{l}\text { G. Indicators of } \\
\text { Results }\end{array}$} & G1. Operation incomes (thousands of euros) & $\mathrm{I}_{21}$ \\
\hline & G2. Ordinary results befote taxes (thounsands of euros) & $\mathrm{I}_{22}$ \\
\hline & G3. Economic profitability (\%) & $\mathrm{I}_{23}$ \\
\hline & G4. Financial profitability $(\%)$ & $\mathrm{I}_{24}$ \\
\hline
\end{tabular}

${ }^{1}$ Following to Rondán et al. (2007), royalties and entry fees with a fixed amount have been changed to percentages. To make this change, we have calculated the percentage of them regarding the invoicing of the first year operating. In other case, we have calculated the percentage regarding the total investment.

${ }^{2}$ Also following to Rondán et al. (2007), we have considered 25 years for an agreement with unlimited or indefinite duration versus other studies considering 100 years.

Source: own elaboration. 
For example, a franchisor that quickly opens 500 units in its first year probably has accumulated less knowledge than a franchisor that has gradually obtained a size of 500 franchisee units in ten years.

Each indicator shows the situation of each franchisor as regards one particular aspect. This enables the potential franchisee to assess a specific aspect of the chain although, at the same time, it remains necessary to attain a combined assessment of the various strategic dimensions, so that the potential franchisee can make an informed comparison between the different franchisors.

\section{Methodology}

Despite the greater acceptance of composite indicators as useful analytical tools for decision-making and communicating information (Saisana, Tarantola 2002), the formalisation of these tools implicitly includes subjective selections adopted by the analyst which may determine the results obtained. In order to counteract the critical aspects associated with the degree of subjectivity, methodologies have been developed to obtain composite indicators thereby reducing the number of decisions the analyst must make (Munda 2005; Vyas, Kumaranayake 2006; González-Laxe, Castillo 2007; Munda, Nardo 2009; Ramon et al. 2012). Nevertheless, the final selection of the aggregation procedure should depend on the purpose for which it is constructed as well as the nature of the material assessed (Ginsberg et al. 1986; Esty et al. 2005).

In this study, the initial indicator system assesses the strategic dimensions of the franchises in a specific sector. This information, which cannot be modified in the short term, should confirm the franchisee's decision of the most suitable franchise. The aim of a composite indicator is to provide, in one single measure, the greatest possible amount of system information, so that, by means of a ranking of franchises using the composite indicator values as a base, the franchisee is capable of distinguishing between the different brands. Furthermore, these composite indicator values should be kept simple and easy to interpret since franchisees are seldom experts in decision-making.

A set of $n$ brands assessed though an initial system of $m$ indicators are considered, expressed in various units of measurement. The value of the indicator $j$ for the unit or brand $i$ is expressed as $I_{i j}$. In order to simplify the formulation of the composite indicator procedure, it is assumed that the initial system is composed of positive indicators, that is to say, the higher the value, the better the situation reflected of the concept under analysis.

\section{The aggregation procedure}

From among the various aggregation procedures currently in practice, the two most widely used according to OECD (2008) are the additive weighted aggregation (AWA) and the weighted product method (WPM). Taken into account all the advantages of the WPM method, it has been selected for the construction of composite indicators. 


\section{Determination of the weighting system}

Once the aggregation rule has been chosen, it is necessary to determine the manner in which the weights assigned to the initial indicators are to be obtained. To this end, the multiplicative optimisation approach proposed by Zhou, Ang and Zhou (2010) is used as a starting point. This approach provides composite indicators by fixing the weights for each unit endogenously. Specifically, this method fixes the weights that allow each unit to obtain the highest possible value for the composite indicator by giving greater weight to indicators that constitute strengths for each unit.

The final objective of the proposed procedure is to establish a composite indicator which enables the drawbacks identified in the previous model to be counteracted as far as possible. The values of the initial indicators are therefore expressed using a scale of measurement which complies with the requirement demanded by a multiplicative aggregation (non-null values, superior to the unit). In order to achieve the desired scale for the initial data, we propose the application of a minimum-maximum standardisation (also referred to as rescaling or stretching) which expresses the data on a non-dimensional scale with a minimum value of 10 and a maximum value of 100 .

\section{Establishing a common weighting system}

Once the initial system has been standardised, in order to counteract the drawback arising from the specificity of the weights obtained through the Zhou, Ang and Zhou model, it is necessary to specify a common weight vector for all the units analysed (Roll et al. 1991). From among the methodologies proposed for the creation of common weights we use those methods that base the estimation on minimising the distance of the composite indicator with common weights (which we call a global composite indicator) to an ideal reference value (Despotis 2002, 2005; Kao, Hung 2005). The ideal value taken as reference is the value of the composite indicator provided by Zhou, Ang and Zhou model.

In order to determine the degree of proximity between the value of the global composite indicator and the ideal value, the following general definition of the set of distance measurements is given:

$$
D_{p}=\sum_{i=1}^{n}\left(C I_{i}^{*}-\prod_{j=1}^{m} I N_{i j}^{w_{j}}\right)^{p} \quad \text { with } p \geq 1,
$$

where $p$ represents the parameter which defines the distance measurement used. Thus, a global composite indicator constructed from a common-weight vector, may be established as the solution for:

$$
\begin{aligned}
& \operatorname{Min} \sum_{i=1}^{n}\left(C I_{i}^{*}-\prod_{j=1}^{m} I N_{i j}^{w_{j}}\right)^{p} \\
& \text { s.t. } \prod_{j=1}^{m} I N_{i j}^{w_{j}} \leq e, \quad i=1, \ldots, n, \\
& w_{h j} \geq 0.000001, \quad j=1, \ldots, m .
\end{aligned}
$$


The value of the global composite indicator with common weights obtained from the model is determined by $G C I_{i} \prod_{j=1}^{m} I N_{i j}^{w_{j}}$, with a weight vector established in (2).

The value of the composite indicator varies depending on the value given to the parameter $p$. When performing an empirical analysis, the analyst must always investigate and carry out tests to analyse the results obtained with various distances, making a final decision based on the conclusions drawn from this analysis.

\section{Incorporating additional restrictions}

Although the previous model establishes a set of common weights, it allows a certain liberty in the selection of the weights for each of the indicators in the initial system. Hence, it is possible that, although the units are analysed from the same point of view, extreme results or situations may be obtained. Amongst these, especially when starting from a very broad system of indicators, is the case where practically null weights are assigned to a large part of the initial indicators, so that they do not contribute to the value of the composite indicator. In this case, an important loss of information is produced, which means that the measurement obtained may be based on only a small number of indicators. Given the objectives of this work, this situation is unacceptable.

To overcome this drawback, additional restrictions to the initial problem are established (Sarrico, Dyson 2004) to ensure that an adequate set of weights is obtained. Specifically, restrictions defined by the virtual values of the indicators of different categories are used (Cherchye et al. 2007). The aim of these restrictions is to limit the importance of the dimensions within the composite indicator, by establishing absolute boundaries $(\varepsilon)$ for the ratio between the product of the virtual values of the indicators included in a specific dimension $(D s)$ and the value of the composite indicator:

$$
\left(\prod_{j=1}^{m} I N_{i j}^{w_{j}}\right)^{\varepsilon} \leq \prod_{j \in D_{s}} I N_{i j}^{w_{j}} \quad \text { with } s=1, \ldots, S,
$$

where $D_{s}$ represents the set of sub-indices of the conceptual dimension $s$, with a total of the $S$ dimensions being considered in the study.

Thus, our aim is to guarantee a minimum common weight for each dimension to ensure that all the indicators in the system supply information to the final composite indicator, thereby preventing the loss produced when the weightings practically annul each other. Given the inexistence of procedures for the establishment of the value of the boundaries of the restrictions, we propose defining an objective criterion to assign these boundaries a value and to increase the discriminatory power of the indicator: the proposed criterion is to fix the highest boundary value $(\varepsilon)$ which can be established as the minimum weight of each dimension. This maximum value is established by the following programming problem: 
F. J. Blancas-Peral et al. Choosing a travel agency franchise by mean of a global composite...

$$
\begin{aligned}
& \varepsilon^{*}=\max \varepsilon, \\
& \text { s.t. } \quad \prod_{j=1}^{m} I N_{i j}^{w_{j}} \leq e, \quad i=1, \ldots, n, \\
& \left(\prod_{j=1}^{m} I N_{i j}^{w_{j}}\right)^{\varepsilon} \leq \prod_{j \in D_{s}} I N_{i j}^{w_{j}}, \quad s=1, \ldots, S, \\
& w_{h j} \geq 0.000001, \quad j=1, \ldots, m,
\end{aligned}
$$

The establishment of this boundary substantially reduces the number of units which reach the maximum value of the composite indicator, thereby increasing its discriminatory power. In this manner, we reformulate the global composite indicator by incorporating these additional restrictions as follows:

$$
\begin{array}{lll}
\operatorname{Min} & \sum_{i=1}^{n}\left(C I_{i}^{*}-\prod_{j=1}^{m} I N_{i j}^{w_{j}}\right)^{p}, & \\
\text { s.t. } & \prod_{j=1}^{m} I N_{i j}^{w_{j}} \leq e, & i=1, \ldots, n, \\
& \left(\prod_{j=1}^{m} I N_{i j}^{w_{j}}\right)^{\varepsilon^{*}} \leq \prod_{j \in D_{s}} I N_{i j}^{w_{j}}, & s=1, \ldots, S, \\
& w_{j} \geq 0.000001, & j=1, \ldots, m .
\end{array}
$$

The use of value $\varepsilon^{*}$ to establish the restrictions which guarantee a minimum weight for each dimension generally implies that the solution obtained will be unique, and remains independent of the value of the parameter $p$. However, we maintain the distance function in the formulation so that it remains possible to choose between the multiple solutions.

\subsection{Data from the travel agency franchise sector in Spain}

The travel agency sector is one of those which arouse the most interest among investors, mainly due to the attractiveness of the business. Franchising is a good option for many firms who want to overcome the crisis by the expansion of their brand.

The travel agency industry under the franchising system was formed (in 2009) from a total of 42 chains and 5095 establishments, according to the data supplied by Tormo \& Associates Consulting.

The main characteristics of a commercial establishment within the travel agency franchise industry are explained in Table 2.

A detailed study of the sector has allowed us to identify a total of 39 franchise chains in Spain. In order to assess the numerous strategic dimensions, we created a suitable database to quantify the indicators which comprise the system presented in Section two. 
Table 2. Typical commercial establishment of travel agency franchises in Spain.

\begin{tabular}{|l|l|}
\hline Business established & Alter the late $80^{\prime}$ \\
Franchising since & Alter the late 90' \\
Initial investment & $22834 €$ \\
Entry fee $^{1}$ & $8377 €$ \\
Royalty & $1.65 \%$ \\
Advertising fee & $0.97 \%$ \\
Contract length & 5 years \\
Minimum dimensions & $30 \mathrm{~m} 2$ \\
Minimum personnel & $1-2$ employees \\
Minimum population & 5000 residents \\
\hline
\end{tabular}

${ }^{1}$ In most cases, the entry fee is included in initial investment.

Source: own elaboration.

The data was obtained from franchise guides published by consultants and franchise associations in Spain for the year 2010. The specific directories used were MundoFranquicia, Tormo, Infofranquicias, Areafranquicia and Barbadillo. When no information was available by these means, it was obtained by following imputation methods for lost causes (OECD 2008).

As indicated by Rondán et al. (2010), the directories are frequently used in research on franchising and, although the data is provided by the franchisors themselves, certain researchers state that these directories contain no significant gaps (Shane 1996; Combs, Castrogiovanni 1994) since their validity is obtained by using rigorous criteria for the inclusion of the data. Financial data was obtained from the IBAS $^{1}$ database, which contains detailed economic and financial information on a large number of Spanish companies.

The main statistics summarising the characteristics of the databases used in the study are shown in Table 3.

Table 3. Statistics summary of strategic indicators

\begin{tabular}{c|c|c|c|c|c|c}
\hline Indicators & Mean value & $\begin{array}{c}\text { Minimum } \\
\text { value }\end{array}$ & $\begin{array}{c}\text { Maximum } \\
\text { value }\end{array}$ & $\begin{array}{c}\text { Standard } \\
\text { deviation }\end{array}$ & $\begin{array}{c}\text { Coefficient of } \\
\text { variation }\end{array}$ & $\begin{array}{c}\text { Variabillity } \\
\text { direction }\end{array}$ \\
\hline $\mathrm{I}_{1}$ & 202.74359 & 1 & 996 & 262.672572 & 1.295590021 & Positive \\
\hline $\mathrm{I}_{2}$ & 98.2820513 & 0 & 3003 & 487.302508 & 4.958204489 & Positive \\
\hline $\mathrm{I}_{3}$ & 94.3073403 & 4.87804878 & 100 & 21.0699793 & 0.223418233 & Positive \\
\hline $\mathrm{I}_{4}$ & 25961.5385 & 4000 & 500000 & 79542.3079 & 3.06385186 & Negative \\
\hline $\mathrm{I}_{5}$ & 17.2662251 & 0.09090909 & 197.3125 & 33.1412804 & 1.919428261 & Positive \\
\hline $\mathrm{I}_{6}$ & 10.8567908 & 0.09090909 & 54.1666667 & 12.5140221 & 1.152644677 & Positive \\
\hline $\mathrm{I}_{7}$ & 24.7648226 & 0 & 207.333333 & 43.4886256 & 1.756064494 & Positive \\
\hline $\mathrm{I}_{8}$ & 14512.9487 & 2000 & 30000 & 7899.51966 & 0.544308383 & Negative \\
\hline
\end{tabular}

${ }^{1}$ SABI, Sistema de Análisis de Balances Ibéricas - Iberian Balance Analysis System, IBAS. 
F. J. Blancas-Peral et al. Choosing a travel agency franchise by mean of a global composite...

End oof Table 3

\begin{tabular}{c|c|c|c|c|c|c}
\hline Indicators & Mean value & $\begin{array}{c}\text { Minimum } \\
\text { value }\end{array}$ & $\begin{array}{c}\text { Maximum } \\
\text { value }\end{array}$ & $\begin{array}{c}\text { Standard } \\
\text { deviation }\end{array}$ & $\begin{array}{c}\text { Coefficient of } \\
\text { variation }\end{array}$ & $\begin{array}{c}\text { Variabillity } \\
\text { direction }\end{array}$ \\
\hline $\mathrm{I}_{9}$ & 6005.5641 & 0 & 18000 & 5137.0094 & 0.855375001 & Negative \\
\hline $\mathrm{I}_{10}$ & 42.6106503 & 0 & 100 & 32.3198244 & 0.758491695 & Negative \\
\hline $\mathrm{I}_{11}$ & 0.84564103 & 0 & 3 & 0.92525332 & 1.094144316 & Negative \\
\hline $\mathrm{I}_{12}$ & 0.12051282 & 0 & 1.25 & 0.32761457 & 2.718503911 & Negative \\
\hline $\mathrm{I}_{13}$ & 33.974359 & 20 & 55 & 10.7715199 & 0.31704851 & Negative \\
\hline $\mathrm{I}_{14}$ & 1.87179487 & 1 & 8 & 1.12809777 & 0.602682373 & Negative \\
\hline $\mathrm{I}_{15}$ & 8.82051282 & 1 & 25 & 8.44758388 & 0.957720265 & Positive \\
\hline $\mathrm{I}_{16}$ & 1.30769231 & 1 & 2 & 0.4675719 & 0.357554982 & Positive \\
\hline $\mathrm{I}_{17}$ & 67.0188667 & 0 & 100 & 35.9262081 & 0.53606111 & Positive \\
\hline $\mathrm{I}_{18}$ & 21.4102564 & 3 & 100 & 21.8219083 & 1.019226854 & Positive \\
\hline $\mathrm{I}_{19}$ & 8.66666667 & 0 & 31 & 5.8007864 & 0.669321507 & Positive \\
\hline $\mathrm{I}_{20}$ & 12.7435897 & 0 & 89 & 20.6343071 & 1.619191099 & Positive \\
\hline $\mathrm{I}_{21}$ & 58028872.5 & 36593 & 941308588 & 183361540 & 3.159832892 & Positive \\
\hline $\mathrm{I}_{22}$ & 835816.923 & -5826710 & 36811213 & 6095980.02 & 7.29343933 & Positive \\
\hline $\mathrm{I}_{23}$ & -2.62333333 & -106.1 & 44.98 & 24.5472056 & -9.357257527 & Positive \\
\hline $\mathrm{I}_{24}$ & 35.0558974 & -125.29 & 304.3 & 67.0758025 & 1.913395673 & Positive \\
\hline
\end{tabular}

Source: own elaboration.

As this table shows, the strategic indicators are extremely variable in the brands analysed, the majority of which present a coefficient of variation above the unit. This demonstrates the heterogeneity of the features between the brands in the system, and justifies the convenience of carrying out a comparative study from the overview offered by a synthetic indicator.

\section{Results and discussions}

In order to aggregate the system information and obtain the composite indicator values for each of the brands, a multiplicative aggregation procedure was applied. As can be observed in Table 3, the values of the system indicators are not expressed on a scale of measurement which complies with the requirements demanded. Therefore, before aggregating the information, the values of the indicators are standardised by applying the minimum-maximum standardisation procedure, and hence their values are expressed in a non-dimensional scaling range of $[10,100]$.

The resolution of the model (2) enables the value of the ideal composite indicator for each brand to be attained, for which a logarithmic transformation is used in order to incur a lower computational cost. The results obtained, given the high number of indicators in the 
initial system as well as the heterogeneity shown by the group, are equal to the maximum values for all the brands and hence it is impossible to discriminate between them. The specific weights obtained for each brand are very heterogeneous since, in each case, greater weight is given to that indicator or indicators where the brand shows its best position, and a practically null weight is assigned to the rest of the aspects assessed by the system. Starting from the ideal values which have been determined, we seek to establish a common weighting system which minimises the distance between the value of the global composite indicator and its ideal value. In order to measure the distance, the three rules most used in practice $\left(L_{1}\right.$, the Euclidean distance and the $\left.L_{\infty}\right)$ are applied in order to compare the results obtained.

From the detailed analysis of the values obtained for each distance it can be concluded that a reduction in the number of those units which reach the maximum value of the indicator is achieved. However, this number remains high and hence it is still not possible to establish a complete ordering of the brands. An average of $28.21 \%$ of the brands obtain the maximum value, while another $43.59 \%$ present values which are not maximum but equal to each other, and hence complete discrimination between the brands being assessed is not yet possible.

In order to solve this problem, we incorporate additional information by including restrictions which guarantee a common minimum weight for each dimension. To define the minimum importance assigned to each of the seven strategic dimensions in the system, the objective criterion proposed earlier was used, thereby resolving the model (4). In our case, the minimum weight which can be assigned to each dimension is $11.82 \%$.

Having defined the restrictions which limit the weight of each strategic dimension by using the previous maximum value, the value of the composite indicator (logarithmic transformation of the model (5)) can be recalculated. In this case the solution is unique which means that the synthetic indictor is the same regardless of which rule is applied to measure the distance in the objective function. The values obtained for the composite indicator (Table 4) and the value of the common weights finally assigned (Table 5) are given below:

Table 4. Composite indicator with geometric aggregation: final values

\begin{tabular}{c|c|c}
\hline Chain & Composite indicator values & Ranking \\
\hline CARLSON WAGONLIT & 1.000 & 1 \\
\hline VIAJES IBERIA & 0.922 & 2 \\
\hline VIAJES MARSANS & 0.913 & 3 \\
\hline ALMEIDA VIAJES & 0.904 & 4 \\
\hline VIAJES ECUADOR & 0.886 & 5 \\
\hline ZAFIRO TOURS & 0.872 & 6 \\
\hline BARCELO VIAJES & 0.870 & 8 \\
\hline SERCOM & 0.865 & 9 \\
\hline HALCÓN VIAJES & 0.865 &
\end{tabular}


F. J. Blancas-Peral et al. Choosing a travel agency franchise by mean of a global composite...

End oof Table 4

\begin{tabular}{|c|c|c|}
\hline Chain & Composite indicator values & Ranking \\
\hline GRUPO 7 VIAJES & 0.858 & 10 \\
\hline GIRAMONDO & 0.856 & 11 \\
\hline EROSKI VIAJES & 0.852 & 12 \\
\hline VIAJES CRISOL & 0.846 & 13 \\
\hline GRUPO GLAUKA & 0.841 & 14 \\
\hline STOP TRAVEL & 0.839 & 15 \\
\hline GRUPO DESFOTUR & 0.832 & 16 \\
\hline INNOVATUR & 0.827 & 17 \\
\hline MIS MEJORES VACACIONES & 0.818 & 18 \\
\hline VIAJES BONILLA & 0.816 & 19 \\
\hline COSTA ESTE & 0.815 & 20 \\
\hline CRUCEMAR CRUCEROS & 0.815 & 21 \\
\hline GALLERY VIAJES & 0.810 & 22 \\
\hline ATLANTIS VIAJES & 0.809 & 23 \\
\hline ELIGE DESTINO & 0.809 & 24 \\
\hline ESTIVALTOUR & 0.804 & 25 \\
\hline HAPPY TRAVEL & 0.803 & 26 \\
\hline QUALITAS & 0.800 & 27 \\
\hline VIAJES ILTRIDA & 0.794 & 28 \\
\hline GO TRAVEL & 0.791 & 29 \\
\hline PLANTOUR VIAJES & 0.783 & 30 \\
\hline PLANET HOBBY & 0.778 & 31 \\
\hline VIAJES TOUR OASIS & 0.770 & 32 \\
\hline VIAJES INCAVISA & 0.769 & 33 \\
\hline VIAJES NUEVOS HORIZONTES & 0.766 & 34 \\
\hline VIAJES TABORA & 0.763 & 35 \\
\hline VIAJES MARPER TOUR & 0.761 & 36 \\
\hline CHECK IN TRAVEL & 0.757 & 37 \\
\hline AB CLUB DEL VIAJE & 0.754 & 38 \\
\hline VIAJES CARREFOUR & 0.749 & 39 \\
\hline
\end{tabular}

As can be observed, by using the logarithmic transformation of the models referred to for their computation, the final composite indicator values can be expressed in a nondimensional scaling range $[0,1]$, and hence a composite indictor for a complete ranking of the brands is achieved.

Although the final decision depends on franchisee preferences and the starting point of each individual, the analysis of the ranking of each of the indicators can greatly help the potential franchisees in their decision. 
Table 5. Common weighting system associated to global composite indicator

\begin{tabular}{|c|c|c|}
\hline Dimension & Indicator & Common weights \\
\hline \multirow{2}{*}{ D1. Size } & $\mathrm{I}_{1}$ & 0.003868 \\
\hline & $\mathrm{I}_{2}$ & 0.039901 \\
\hline \multirow{2}{*}{ D2. Dispersion } & $\mathrm{I}_{3}$ & 0.002741 \\
\hline & $\mathrm{I}_{4}$ & $0.040700^{1}$ \\
\hline \multirow{3}{*}{ D3. Growth } & $\mathrm{I}_{5}$ & 0.010128 \\
\hline & $\mathrm{I}_{6}$ & 0.031866 \\
\hline & $\mathrm{I}_{7}$ & 0.000010 \\
\hline \multirow{7}{*}{$\begin{array}{l}\text { D4. Cost of adhesion (price of } \\
\text { franchising) }\end{array}$} & $\mathrm{I}_{8}$ & 0.012582 \\
\hline & $\mathrm{I}_{9}$ & 0.000010 \\
\hline & $\mathrm{I}_{10}$ & 0.003104 \\
\hline & $\mathrm{I}_{11}$ & 0.000010 \\
\hline & $\mathrm{I}_{12}$ & 0.022681 \\
\hline & $\mathrm{I}_{13}$ & 0.000010 \\
\hline & $\mathrm{I}_{14}$ & 0.000010 \\
\hline \multirow{2}{*}{ D5. Contract } & $\mathrm{I}_{15}$ & 0.018513 \\
\hline & $\mathrm{I}_{16}$ & 0.020951 \\
\hline \multirow{4}{*}{ D6. Timming } & $\mathrm{I}_{17}$ & 0.005010 \\
\hline & $\mathrm{I}_{18}$ & 0.000010 \\
\hline & $\mathrm{I}_{19}$ & 0.006485 \\
\hline & $\mathrm{I}_{20}$ & 0.026236 \\
\hline \multirow{4}{*}{ D7. Indicators of results } & $\mathrm{I}_{21}$ & 0.000010 \\
\hline & $\mathrm{I}_{22}$ & 0.017047 \\
\hline & $\mathrm{I}_{23}$ & 0.009247 \\
\hline & $\mathrm{I}_{24}$ & 0.005979 \\
\hline
\end{tabular}

${ }^{1}$ The indicator with the highest weight is $\mathrm{I}_{4}$ (minimum population required). Nevertheless, this result must be carefully considered because the first chain in the ranking has an outlier in this variable. The remaining chains have similar values in this variable.

Firstly, an endogenous analysis of the values of the common weights assigned must be carried out. This study makes it possible to obtain a general vision of the framework within which they are being analysed and enables the indicators which are representative of each dimension to be identified. A representative indicator has greater influence over the values of the final indicator and is therefore considered to be of greater importance when assessing the situation of each brand. 
From Table 4, it can be observed that the growth, the size and the dispersion of the franchisor are the major variables in the comparison of travel agencies in franchising and therefore in the ranking of chains. The aspects of contract length, exclusivity and previous experience of the franchisor are ranked as less significant than the previous variables. Finally, entry fees, royalties and operation incomes of the franchisor constitute relatively unimportant variables in the selection of the chain.

The final decision in the choice of franchisor must be based on the factors above and on the characteristics and preferences of the potential franchisee.

Based on the results of Table 4, we suggest that a comparative analysis be carried out on the global situation shown by those brands better placed than the rest, whilst paying special attention to the differences shown between these brands and those more poorly placed, in order to reach conclusions regarding the main strengths of the better-situated brands.

The composite indicator places the franchises which offer competitive advantages associated with the size of the organisation in the top positions. On average, these brands are composed of a network of 618 establishments, of which at least $90 \%$ are situated in Spain, with the exception of the brand Carlson Wagonlit. This high presence in the domestic market offers the Spanish franchisee guarantees as regards knowledge of the market within which the new branch of the franchise would be operating and increases the ease with which the success of other establishments in the chain can be extrapolated.

These larger franchises also display growth dynamics far superior to the rest with an average of 57 establishments since the company was founded. This positive tendency is maintained in Spain, with a mean tendency of 18 establishments opened per year. In this way, the better-placed franchises offer a stronger presence in the market, which in some way guarantees a flow of positive demand for future activities.

As regards the joining fee, the better-placed brands require an average investment of $21,211 €$ and show a comparative advantage as regards product publicity services, since no obligatory monthly fee for advertising is levied.

On the other hand, in at least $80 \%$ of cases, these brands offer their contracts in an exclusive sales area for business activity where there is no competition for the sale of the products or services of the franchisee, since the franchisor undertakes not to grant concessions to third parties to open centres within the said area. These brands therefore offer a good margin of safety which guarantees that significant economic benefits will be obtained due to the absence of direct competition.

Moreover, the brands indicated as being the best possible option have a great deal of experience in granting franchises. On average, they have been establishing franchise contracts for 42.8 years.

Finally, the strengths of the best brands include the implementation of highly effective business strategies. Therefore, the strategic behaviour of these organisations allows them to obtain an average lifetime income before taxes of over 8 million Euros. Moreover, when analysing these results in relative terms by considering the means and resources available in each case, these organisations reach economic profitability indices of approximately $4.92 \%$. 
The greater or lesser adaptation of this characterisation to the franchisee's preferences may sway the final decision. This means that the synthetic indicator is a useful analytical instrument which provides a global vision of the situation of each brand when all the strategic aspects evaluated in the initial system are simultaneously assessed.

\section{Managerial implications and conclusions}

The specific aim of this work is to help potential franchisees through the process of selecting a franchisor. The potential franchisee has to analyse a large volume of information obtained from the directories published by franchise associations and consultants, and hence we propose a procedure which enables the relevant information to be summarised and presented simply so that the potential franchisee can easily and clearly identify the strongest chains in a certain sector.

An important aspect of this paper is that the data was obtained from a market (the Spanish market) that is fully developed in the franchise area. In this sense, experienced franchisors are better suited to identify qualified franchisees. In fact, many franchisors, when selecting franchisees, change the characteristics required of potential franchisees owing to the experience that they have gained over time. Therefore, using data from franchisors who operate in a consolidated market yields greater reliability and accuracy of results.

To this end a global composite indicator is proposed, which starts from a series of unitary indicators grouped together in strategic dimensions. This indicator enables a ranking of the franchisors in the travel agency sector to be developed. Moreover, an evaluation of the indicators with greater influence over the value of the global composite indicator is obtained by means of a procedure which applies the lowest possible degree of subjectivity. Hence an exhaustive analysis is achieved of the travel agency sector operating under the franchise system.

In particular, the first positions in the ranking of travel agencies in franchising in Spain feature the chains Carlson Wagonlit, Viajes Iberia, Viajes Marsans, Almeida Viajes, and Viajes Ecuador. In contrast, the last positions in the ranking are occupied by the chains Viajes Tábora, Viajes Marper Tour, Check in Travel, AB Club del Viaje, and Viajes Carrefour. In addition to the ranking of travel agencies in franchising, this work determines those variables with the most influence in the creation of this ranking. These variables are the number of outlets of the chain worldwide, the outlets opened per year in Spain, and the years between inception and the creation of the first franchise of the company.

The results show that the number of franchisees is therefore a major variable to be taken into account when the choice of the franchisor is made by the future franchisees. In addition, experience accumulated by each franchisor should have a good effect on many aspects, such as the improvement of the learning process that is carried out with franchisees, a more effective fixation of payments, and the location of the stores in strategic geographic zones. 
Another significant conclusion is that the number of outlets opened per year in Spain constitutes a major indicator, while the total number of outlets opened per year worldwide since the inception of the franchise system is considered of low relevance. This means that the domestic franchising perspective should be taken into account by franchisees instead of the international perspective, since, in most countries, the bulk of franchising chains are national (Ramírez-Hurtado et al. 2011).

On the other hand, variables related to the cost of adhesion are largely deemed as unimportant in the choice of franchisor. Nevertheless, the results of this work show that the cost of adhesion is not a crucial variable: if the candidate fails to reach the minimum financial level required for the possible incorporation into a franchising chain, then this potential franchisee is prohibited from joining any franchising chain, and hence it is inappropriate to analyse the importance of this attribute.

In short, the number of outlets of the chain worldwide, the outlets opened per year in Spain, and the years between inception and the creation of the first franchise of the company constitute the 3 principal factors to be taken into account by potential franchisees in their selection of a franchisor, while those variables related with the cost of adhesion remain of relatively low importance.

One drawback, common to any information aggregation process, is the loss of information incurred during this procedure. The final assessment of each chain is based on a unique global value; however, this limitation can be overcome by carrying out a more detailed analysis of the individual values.

Future lines of research include the possibility of extending the methodology for other sectors, once an adequate selection of indicators, dimensions and other factors has been made. It would also be of interest to improve the current methodology, such as by applying the use of a no-ties methodology.

\section{Acknowledgement}

The authors wish to thank the two anonymous reviewers for their helpful comments which have contributed significantly towards the improvement of this paper.

\section{References}

Al-Khalifa, A. K.; Peterson, S. E. 1999. The partner selection process in international joint ventures, European Journal of Marketing 33(11/12): 1064-1079.

http://dx.doi.org/10.1108/03090569910292276

Altinay, L. 2006. Selecting partners in an International Franchise Organisation, International Journal of Hospitality Management 25(1): 108-128. http://dx.doi.org/10.1016/j.ijhm.2004.12.013

Altinay, L.; Wang, C. L. 2006. The role of prior knowledge in international franchise partner recruitment, International Journal of Service Industry Management 17(5): 430-444.

http://dx.doi.org/10.1108/09564230610689768

Bates, T. 1995. A comparison of franchisee and independent small business survival rates, Small Business Economics 7: 377-388. http://dx.doi.org/10.1007/BF01302738

Carney, M.; Gedajlovic, E. 1991. Vertical integration in franchise systems: agency theory and resource explanations, Strategic Management Journal 12(8): 607-629.

http://dx.doi.org/10.1002/smj.4250120804 
Castrogiovanni, G. J.; Bennet, N.; Combs, J. G. 1995. Franchisor types: reexamination and clarification, Journal of Small Business Management 33(1): 45-55.

Castrogiovanni, G. J.; Justis, R. T.; Julian, S. D. 1993. Franchise failure rates: an assessment of magnitude and influencing factors, Journal of Small Business Management 31(2): 105-114.

Cherchye, L.; Moesen, W.; Rogge, N.; Puyenbroeck, T. 2007. An introduction to 'benefit of the doubt' composite indicators, Social Indicators Research 82(1): 111-145.

http://dx.doi.org/10.1007/s11205-006-9029-7

Clarkin, J. E.; Swavely, S. M. 2006. The importance of personal characteristics in franchisee selection, Journal of Retailing and Consumer Services 13(2): 133-142.

http://dx.doi.org/10.1016/j.jretconser.2005.08.008

Combs, J. G.; Castrogiovanni, G. J. 1994. Franchisor strategy: a proposed model and empirical test of franchise versus company ownership, Journal of Small Business Management 32(2): 37-48.

Dant, R. P. 1995. Motivation for franchising: rhetoric versus reality, International Small Business Journal 14(1): 10-32. http://dx.doi.org/10.1177/0266242695141001

Despotis, D. K. 2002. Improving the discriminating power of DEA: focus on globally efficient units, Journal of the Operational Research Society 53: 314-23.

http://dx.doi.org/10.1057/palgrave.jors.2601253

Despotis, D. K. 2005. A Reassessment of the human development index via data envelopment analysis, Journal of the Operational Research Society 56: 969-980.

http://dx.doi.org/10.1057/palgrave.jors.2601927

Elango, B.; Fried, V. H. 1997. Franchising research: a literature review and synthesis, Journal of Small Business Management 35(3): 69-81.

Esty, D. C.; Levy, M.; Srebotnjak, T.; Sherbinin, A. 2005. Environmental Sustainability Index: Benchmarking National Environmental Stewardship. Yale Center of Environmental Law and Policy, New Haven, Conn.

Franquiciashoy. 2008. Agencias de viajes: Pasaporte hacia la independencia [online]. Available from Internet: www.franquiciashoy.es

Forward, J.; Fulop, C. 1993. Elements of a franchise: the experiences of established firms, The Service Industries Journal 13(4): 159-178. http://dx.doi.org/10.1080/02642069300000067

Ginsberg, N.; Osborn, J.; Blank, G. 1986. Geographic perspectives on the wealth of nations, Department of Geography Research Paper No. 220. University of Chicago, Chicago.

González-Laxe, F.; Castillo, J. I. 2007. A port competitiveness indicator through the multicriteria decision method PROMETHEE. A practical implementation to the Spanish port system, in $\mathrm{An}$ nual Conference, July, 2007. International Association of Maritime Economist IAME.

Guilloux, V.; Gauzente, C.; Kalika, M.; Dubost, N. 2004. How france's potential franchisees reach their decisions: a comparison with franchiser' perceptions, Journal of Small Business Management 42(2): 218-224. doi:10.1111/j.1540-627X.2004.00107.X

Jambulingam, T.; Nevin, J. R. 1999. Influence of franchisee selection criteria on outcomes desired by the franchisor, Journal of Business Venturing 14(4):363-395.

http://dx.doi.org/10.1016/S0883-9026(98)00023-8

Kao, C.; Hung, H. T. 2005. Data envelopment analysis with common weights: the compromise solution approach, Journal of the Operational Research Society 56: 1196-1203.

http://dx.doi.org/10.1057/palgrave.jors.2601924

Kaufmann, P. J. 1999. Franchising and the choice of self-employment, Journal of Business Venturing 14(4): 345-362. http://dx.doi.org/10.1016/S0883-9026(98)00021-4

Kaufmann, P. J.; Stanworth, J. 1995. The decision to purchase a franchise: a study of prospective franchisees, Journal of Small Business Management 33(4): 22-32. 
F. J. Blancas-Peral et al. Choosing a travel agency franchise by mean of a global composite...

Knight, R. M. 1986. Franchising from the franchisor and franchisee points of view, Journal of Small Business Management 24(3): 8-15.

Lim, J.; Frazer, L. 2003. Franchisee-franchisor compatibility: it's a two-way street, in Australian \& New Zealand Marketing Academy, in ANZMAC Conference, 2003, Adelaide.

López, M. B.; Ventura, J. 2002. Integración vertical y costes de aparición de la franquicia, Revista Europea de Dirección y Economía de la Empresa 11(4): 55-74.

Munda, G. 2005. Measuring sustainability: a multi-criterion framework, environment, Development and Sustainability 7: 117-34. http://dx.doi.org/10.1007/s10668-003-4713-0

Munda, G.; Nardo, M. 2009. Noncompensatory/nonlinear composite indicators for ranking countries: a defensible setting, Applied Economics 41:1513-1523.

http://dx.doi.org/10.1080/00036840601019364

OECD 2008. Handbook on Constructing Composite Indicators. Methodology and User Guide. OECD Publications, Paris

Ordiñaga, S. 1995. Cómo seleccionar un franquiciador, Distribución y Consumo 23: 85.

Pereira, J.; Claver, E.; Molina, J. F. 2009. Influencia de los grupos estratégicos sobre el rendimiento empresarial: un Enfoque Multinivel, Investigaciones Europeas de Dirección y Economía de la Empresa 15(1): 185-202.

Peterson, A.; Dant, R. P. 1990. Perceived advantages of franchise option from the franchisee perspective: empirical insights from a service franchise, Journal of Small Business Management 28(3): 46-61.

Porter, M. E. 1979. How competitive forces shape strategy, Harvard Business Review 57(2): 137-145.

Rahatullah, M. K.; Raeside, R. 2009. The dynamism of partner selection criteria in franchising, S.A.M. Advanced Management Journal 74(4): 36-46.

Ramirez-Hurtado, J. M.; Quattrociocchi, B. 2009. Franchisee motivations: a study in Spain, Journal of Applied Economic Sciences 4(2): 210-220.

Ramírez-Hurtado, J. M.; Rondán-Cataluña, F. J.; Guerrero-Casas, F. M.; Berbel-Pineda, J. M. 2011. Identifying the franchisee profiles franchisors prefer, Journal of Business Economics and Management 12(4): 567-588. http://dx.doi.org/10.3846/16111699.2011.599408

Roll, Y.; Cook, W. D. and Golany, B. 1991. Controlling factor weights in data envelopment analysis, IIE Transactions 23(1): 2-9. http://dx.doi.org/10.1080/07408179108963835

Rondán, F. J.; Navarrro, A.; Díez, E. C. 2007. Proposing new variables for the identification of strategic groups in franchising, International Entrepreneurship and Management Journal 3(4): 355-377. http://dx.doi.org/10.1007/s11365-007-0043-2

Rondán, F. J.; Navarro, A.; Díez, E. C.; Rodríguez, C.; Guisado, M. 2010. Estudio del performance de los grupos estratégicos en el sistema de franquicia español, Investigaciones Europeas de Dirección y Economía de la Empresa 16(2): 43-62.

Sarrico, C. S.; Dyson, R. G. 2004. Restricting virtual weights in data envelopment analysis, European Journal of Operational Research 159: 17-34.

http://dx.doi.org/10.1016/S0377-2217(03)00402-8

Shane, S. 1996. Why franchise companies expand overseas, Journal of Business Venturing 11(2): 73-88. http://dx.doi.org/10.1016/0883-9026(95)00110-7

Saisana, M.; Tarantola, S. 2002. State - of - the - Art Report on Current Methodologies and Practices for Composite Indicator Development. Joint Research Centre, European Commission.

Stanworth, J. 1995. The franchise relationship: entrepreneurship or dependence, Journal of Marketing Channels 4(1/2): 161-176. doi:10.1300/J049v04n01-10

Taylor, S. 2000. Hotels, in C. Lashley, A. Morrison (Eds.). Franchising hospitality services. Oxford: Butterworth Heinemann, 170-191. http://dx.doi.org/10.1016/B978-0-7506-4772-4.50012-8 
Vaishnav, T.; Altinay, L. 2009. The franchise partner selection process and implications for India, Worldwide Hospitality and Tourism Themes 1(1): 52-65.

http://dx.doi.org/10.1108/17554210910949887

Vyas, S.; Kumaranayake, L. 2006. Constructing socio-economic status indices: how to use principal components analysis, Health Policy and Planning 21: 459-468.

http://dx.doi.org/10.1093/heapol/czl029

Weaven, S.; Frazer, L. 2006. Investment incentives for single and multiple unit franchisees, Qualitative Market Research: an International Journal 9(3): 225-242.

http://dx.doi.org/10.1108/13522750610671662

Withane, S. 1991. Franchising and franchisee behaviour: an examination of opinions, personal characteristics and motives of Canadian franchisee entrepreneurs, Journal of Small Business Management 29(1): 22-29.

Williams, D. L. 1999. Why do entrepreneurs become franchisees? An empirical analysis of organizational choice, Journal of Business Venturing 14(1): 103-124.

http://dx.doi.org/10.1016/S0883-9026(97)00100-6

Xiao, Q.; Neill, J. O. W.; Wang, H. 2008. International hotel development: a study of potential franchisees in China, International Journal of Hospitality Management 17(3): 325-336.

http://dx.doi.org/10.1016/j.ijhm.2007.10.006

Zhou, O.; Ang, B. W.; Poh, K. L. 2006. Comparing aggregating methods for constructing the composite environmental index: an objective measure, Ecological Economics 59: 305-311.

http://dx.doi.org/10.1016/j.ecolecon.2005.10.018

Zhou, P.; Ang, B. W.; Zhou, D. Q. 2010. Weighting and aggregation in composite indicators construction: a multiplicative optimization approach, Social Indicators Research 96: 169-181. http://dx.doi.org/10.1007/s11205-009-9472-3

Francisco Javier BLANCAS-PERAL is Assistant Professor in the Department of Economics, Quantitative Methods and Economic History at Pablo de Olavide University (Seville, Spain). He has publications in more than twenty-five national and international conference proceedings. His research focused on constructing composite indicators and sustainable tourism analysis. He has published some research papers in international journals that are taken are reference in composite indicators literature. Among these journals Ecological Indicators, Ecological Economics, Social Indicator Research, Journal of Gender Studies or Science of the Total Environment can be remarked

Ignacio CONTRERAS is Associate Professor in the Department of Economics, Quantitative Methods and Economic History, Pablo de Olavide University of Seville, Spain. His research topics include DEA, multicriteria decision analysis and group decision making process. He has published several papers in journals like European Journal of Operational Research, Decision Support Systems, Journal of the Operational Research Society or Group Decision and Negotiation, among others.

José Manuel RAMIREZ-HURTADO. He is Assistant Professor in the Department of Economics, Quantitative Methods and Economic History at Pablo de Olavide University (Seville, Spain). He received his $\mathrm{PhD}$ in Applied Economics from Pablo de Olavide University in 2007. His main research interests include franchising, preference studies, marketing management and tourism analysis. In 2008 he was awared the Spanish National Award in Franchising from the Salón Internacional de la Franquicia, las Oportunidades de Negocio y el Comercio Asociado (SIFandCo). He has published papers in journals such as Journal of Business Economics and Management, Service Business, Journal of Applied Economic Sciences, Journal of Quantitative Methods for Economics and Business Administration and Tourism Analysis. 